\title{
Familial acute necrotizing encephalopathy
}

INSERM

\section{Source}

INSERM. (1999). Orphanet: an online rare disease and orphan drug data base. Familial acute necrotizing encephalopathy. ORPHA:88619

Familial acute necrotizing encephalopathy or ADANE is a potentially fatal neurological disease characterised by neuropathological lesions principally involving the brainstem, thalamus and putamen. 